\title{
MALT1-Deficient Mice Develop Atopic-Like Dermatitis Upon Aging
}

\author{
Annelies Demeyer ${ }^{1,2}$, Elien Van Nuffel ${ }^{1,2}$, Griet Baudelet ${ }^{1,2}$, Yasmine Driege ${ }^{1,2}$, \\ Marja Kreike ${ }^{1,2}$, David Muyllaert ${ }^{1,2}$, Jens Staal ${ }^{1,2 *+}$ and Rudi Beyaert ${ }^{1,2 *+}$ \\ ${ }^{1}$ VIB Center for Inflammation Research, Ghent, Belgium, ${ }^{2}$ Department of Biomedical Molecular Biology, Ghent University, \\ Ghent, Belgium
}

OPEN ACCESS

Edited by:

Karin Loser,

University of Münster, Germany

Reviewed by:

Stephan Hailfinger,

University of Tübingen, Germany

Linda M. McAllister-Lucas,

School of Medicine, University of Pittsburgh, United States

*Correspondence: Jens Staal

jens.staa/@irc.vib-ugent.be Rudi Beyaert

rudi.beyaert@irc.vib-ugent.be

†These authors share last authorship

Specialty section:

This article was submitted to Autoimmune and Autoinflammatory

Disorders,

a section of the journal

Frontiers in Immunology

Received: 31 May 2019 Accepted: 16 September 2019

Published: 01 October 2019

Citation:

Demeyer A, Van Nuffel E, Baudelet $G$, Driege Y, Kreike M, Muyllaert $D$,

Staal J and Beyaert R (2019)

MALT1-Deficient Mice Develop Atopic-Like Dermatitis Upon Aging.

Front. Immunol. 10:2330.

doi: 10.3389/fimmu.2019.02330
MALT1 plays an important role in innate and adaptive immune signaling by acting as a scaffold protein that mediates NF-kB signaling. In addition, MALT1 is a cysteine protease that further fine tunes proinflammatory signaling by cleaving specific substrates. Deregulated MALT1 activity has been associated with immunodeficiency, autoimmunity, and cancer in mice and humans. Genetically engineered mice expressing catalytically inactive MALT1, still exerting its scaffold function, were previously shown to spontaneously develop autoimmunity due to a decrease in Tregs associated with increased effector T cell activation. In contrast, complete absence of MALT1 does not lead to autoimmunity, which has been explained by the impaired effector $\mathrm{T}$ cell activation due to the absence of MALT1-mediated signaling. However, here we report that MALT1-deficient mice develop atopic-like dermatitis upon aging, which is preceded by Th2 skewing, an increase in serum lgE, and a decrease in Treg frequency and surface expression of the Treg functionality marker CTLA-4.

Keywords: atopic dermatitis, skin inflammation, MALT1, lymphocytes, Tregs, Th2, aging

\section{INTRODUCTION}

MALT1 (Mucosa-associated lymphoid tissue lymphoma translocation protein 1) is an intracellular signaling protein that plays an important role in several cell types, including lymphoid and myeloid cells as well as non-hematopoietic cells (1). MALT1 is best known for its role as a scaffold protein in T cell receptor (TCR)- and B cell receptor (BCR)-induced nuclear factor- $\kappa \mathrm{B}$ (NF- $\kappa \mathrm{B}$ ) signaling, leading to the activation and proliferation of $\mathrm{T}$ and $\mathrm{B}$ cells, respectively $(2,3)$. Moreover, MALT1-mediated NF- $\kappa B$ signaling plays a key role in the proliferation of certain $B$ cell lymphomas, such as MALT1 lymphoma and activated B cell-like diffuse large B cell lymphoma (ABC-DLBCL) (4-13). TCR or BCR stimulation, as well as oncogenic mutations in specific signaling proteins, leads to the formation of a so-called CBM signaling complex, consisting of CARD11 (also known as CARMA1), BCL10 and MALT1 (8, 14-18). In this complex, MALT1 acts as an adaptor to recruit the E3 ubiquitin ligase TRAF6, whose activity facilitates the recruitment and activation of downstream NF- $\mathrm{KB}$ signaling proteins (19-21). The importance of the CBM complex is illustrated by the impaired TCR-induced NF- $\mathrm{KB}$ activation in T cells isolated from Card11-, Bcl10-, and Malt1-knock-out (KO) mice, respectively $(2,3,22,23)$.

In addition to its scaffold function, MALT1 also acts as a cysteine protease. TCR stimulation leads to the MALT1-mediated cleavage of several substrates including BCL10, the deubiquitinases A20 and CYLD, the NF- $\kappa$ B family member RelB, the RNA-binding and RNA-destabilizing proteins Roquin-1/2, Regnase-1, and N4BP1, the E3 ubiquitin ligase HOIL1, and MALT1 itself (24-34). 
Although the specific biological role of cleavage of each of these substrates is still largely unclear, MALT1 proteolytic activity contributes to the fine-tuning of TCR-induced gene expression, lymphocyte activation and proliferation, and regulatory $\mathrm{T}$ cell (Treg) development and function. Consequently, inhibition of MALT1 proteolytic activity has been proposed as an interesting therapeutic approach for autoimmune diseases and certain cancers, which is further supported by promising results with MALT1 protease inhibitors in preclinical mouse models (12, 13, 35-37). Of note, MALT1 mutation in humans, causing the absence or very low expression of MALT1, leads to combined immunodeficiency (CID), which is characterized by several bacterial, fungal, and viral infections, indicating that targeting MALT1 activity may not be without risk (38-43). Moreover, it was recently shown that Malt1 protease-dead (PD) knockin mice expressing a catalytically inactive MALT1 mutant spontaneously develop multi-organ inflammation due to defects in $\mathrm{T}$ cell homeostasis (44-49). This was rather unexpected since inflammation was never described for mice that are completely deficient in MALT1. However, in the present paper we show that Malt1-KO mice develop atopic-like dermatitis upon aging.

\section{RESULTS}

\section{Malt1-KO Mice Spontaneously Develop Skin Lesions, Accompanied by Elevated Serum Cytokine Levels}

Malt1-KO mice were housed under SPF conditions and monitored for macroscopic clinical signs on a regular basis. Interestingly, the mice were found to develop skin lesions upon aging, with an average disease onset of 161 days (Figures 1A,B). The Malt1-KO mice suffer from erosive lesions in the neck and face region, with the epidermis showing acanthosis, hyperkeratosis, and parakeratotic scaling, as well as $\mathrm{CD}^{+} \mathrm{T}$ cell infiltration (Figure 1C). Similar lesions were observed in another independent Malt1-KO LacZ reporter mouse line (Figure 1A), indicating that the observed phenotype is strain-independent. Next to full body Malt1-KO mice, also T cell-specific (Malt $1^{F L / F L} \mathrm{CD} 4-\mathrm{Cr} e^{T g /+}$ ) and keratinocyte-specific $\left(\right.$ Malt ${ }^{F L / F L} \mathrm{K5}-\mathrm{Cr} \mathrm{Cg}^{\mathrm{Tg} /+}$ ) Malt1-KO mice were monitored for skin lesions over time, but these mice did not develop any skin lesions (Figure 1B), indicating that absence of MALT1 in $\mathrm{T}$ cells or keratinocytes, as such, is not sufficient to induce skin inflammation. Malt1-KO mice that develop skin inflammation were found to have increased serum levels of the pro-inflammatory cytokines IL-2, IL-4, IL-6, IL-17, IFN- $\gamma$, and TNF (Figure 1D). To assess if increased serum cytokine levels reflect a more general inflammation in MALT1-deficient mice, we analyzed H\&E stained sections of lung, liver, stomach, colon, small intestine, lacrimal glands and salivary glands. However, no differences were observed between Malt1-KO and WT mice for all these tissues (Figure 2A). In addition, we checked blood glucose levels in young ( \pm 20 weeks) and older mice (7-8 months) to determine possible pancreatic inflammation, but also here MALT1 deficiency had no effect (Figure 2B). Together, our data demonstrate that MALT1 deficiency in mice specifically results in an inflammatory skin phenotype upon aging.

\section{MALT1 Deficiency Results in Defective Treg Development and CTLA-4 Expression via a T Cell Intrinsic Mechanism in Both Young and old Mice}

Malt1-KO mice are known to have a defect in Treg development (44, 46, 50, 51), which could be responsible for the skin inflammation in aging MALT1-deficient mice. However, it has been reported by Brüstle et al. that whereas young Malt1-KO mice have severely reduced numbers of Tregs in blood and thymus, 1 year old Malt1-KO mice have normal Treg numbers in blood, which was suggested to reflect the generation of inducible Tregs (iTregs) in aging mice (51). Of note, this study did not mention the development of skin lesions in aged mice. We therefore analyzed the number of Tregs (Foxp $3^{+} \mathrm{CD} 25^{+} \mathrm{CD} 4^{+}$ $\mathrm{T}$ cells) in young and aged ( \pm 7 months old) Malt1-KO mice. In agreement with the above mentioned previous studies, Treg numbers were reduced in thymus, lymph nodes (LN), and spleen of lesion-free young mice. However, in contrast to the study by Brüstle et al., we found that the number of Tregs were equally reduced in thymus, $\mathrm{LN}$ and spleen of aged Malt1-KO mice that developed skin lesions (Figures 3A,B and gating strategy in Supplementary Figures 1, 2). The reason for this discrepancy is still unclear, but different findings may reflect specific differences in mouse housing conditions. Similar to the full Malt1-KO mice, also T cell specific Malt1-KO mice had a reduced Treg frequency in their thymus, spleen, and LN (Figure 3C), indicating a $\mathrm{T}$ cell intrinsic role of MALT1 in Treg development. We next investigated whether the remaining MALT1-deficient Tregs are functional. CTLA-4 expression on Tregs is known to compete with CD28 on T cells for binding to CD80 and CD86, as well as to reduce the surface expression of CD80 and CD86 on antigen presenting cells, resulting in reduced $\mathrm{T}$ cell proliferation and cytokine production $(52,53)$. We therefore assessed CTLA4 surface expression on splenocytes from WT and Malt1$\mathrm{KO}$ mice that were stimulated in vitro for $4 \mathrm{~h}$ with phorbol myristic acid/Ionomycine (PMA/IO). As shown in Figure 3D, a reduced frequency of Tregs that express surface CTLA- 4 could be observed in Malt1-KO mice compared to WT mice, suggesting that the remaining MALT1-deficient Tregs are functionally impaired (gating strategy in Supplementary Figure 2).

\section{Activation and CTLA-4 Surface Expression of CD4 ${ }^{+} \mathrm{T}$ Cells Is Altered in Malt1-KO Mice}

Since we observed increased $\mathrm{CD}^{+}{ }^{+} \mathrm{T}$ cell infiltration in the diseased skin of Malt1-KO mice, we further investigated whether the proliferation and activation of $\mathrm{CD} 4^{+} \mathrm{T}$ cells is affected in MALT1-deficient mice. For this purpose, we purified $\mathrm{CD} 4^{+} \mathrm{T}$ cells and labeled them with CFSE to measure their proliferation after $72 \mathrm{~h}$ stimulation with anti-CD3 and anti-CD28. This showed that MALT1-deficient CD4 ${ }^{+}$T cells can proliferate, albeit to a lesser extent than WT CD4 ${ }^{+} \mathrm{T}$ cells (Figure 4A), which is similar to what has previously been described (45). To assess 
A

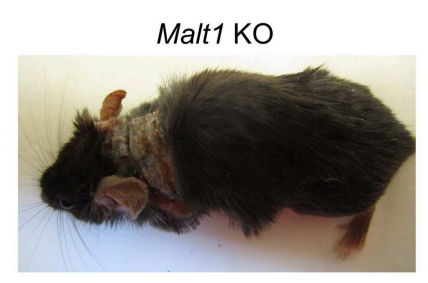

Malt1 KO LacZ

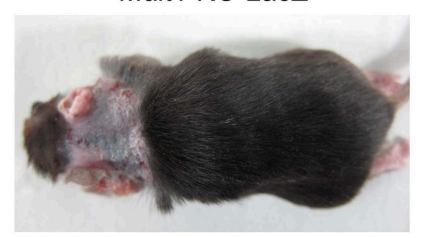

B

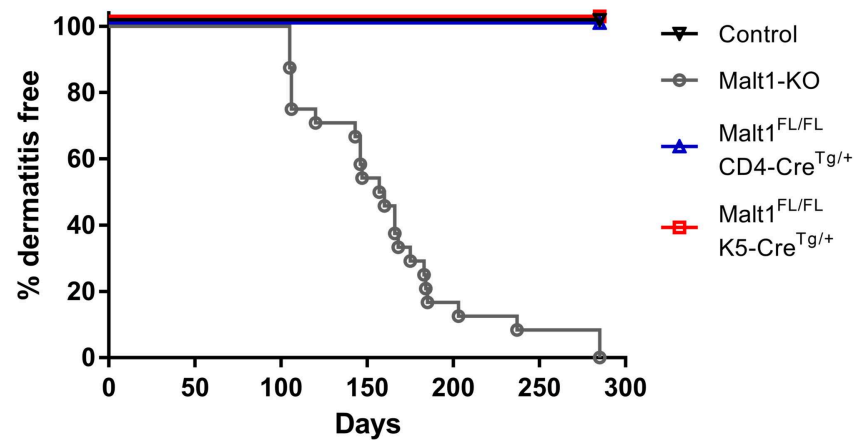

C
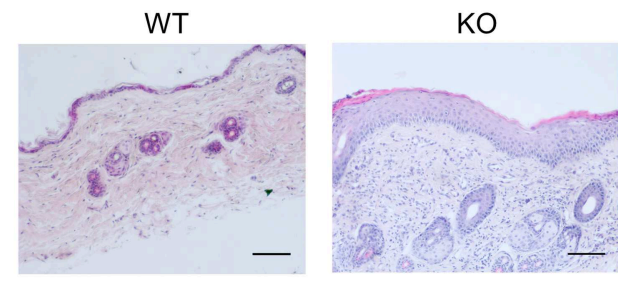

H\&E

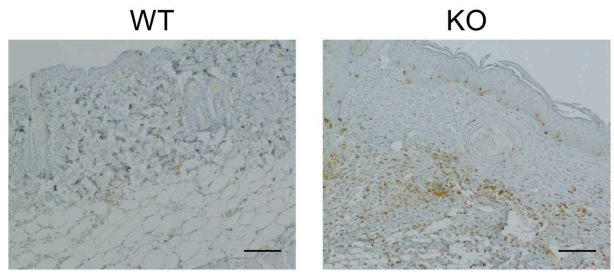

a-CD3
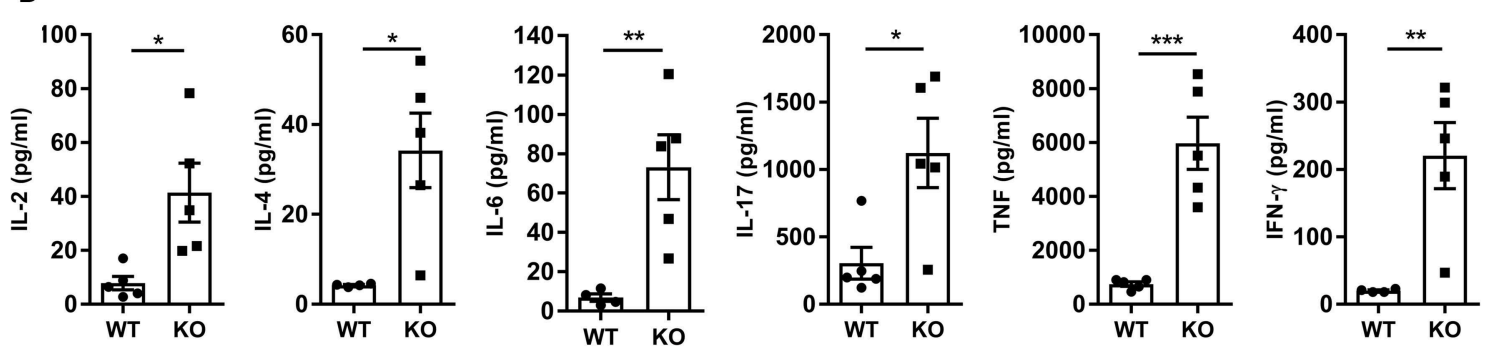

FIGURE 1 | Malt1-KO mice develop skin lesions at late age accompanied by elevated serum cytokine levels. (A) Skin lesion in the neck of a Malt1-KO and Malt1-KO LacZ mouse. (B) Incidence of dermatitis in Malt1-KO mice ( $n=8$ for controls, $n=24$ for Malt1-KO, $n=6$ for Malt1 FL/FL CD4-Cre ${ }^{T g} /+$, and $n=6$ for Malt1 FL/FL K5-Cre ${ }^{T g /+}$ ). (C) H\&E staining on WT and Malt1-KO skin (scale bar $100 \mu \mathrm{m}$ ), showing epidermal thickening and parakeratosis in Malt1-KO skin and $\alpha-C D 3$ staining on WT and Malt1-KO skin (scale bar $100 \mu \mathrm{m}$ ), showing increased CD3 staining in Malt1-KO skin. (D) Elevated serum levels of IL-2, IL-4, IL-6, IL-17, IFN- $\gamma$, and TNF in Malt1-KO mice compared to WT mice (both $n=5$ and $>30$ weeks, and Malt1-KO mice have AD). Open circles (WT) and black squares (KO) represent individual mice. The mean ${ }^{ \pm}$SEM is indicated on the graphs. The statistical significance between groups was calculated with an unpaired 2 -tailed Student's $t$-test: ${ }^{\star} P<0.05$, ${ }^{\star \star} P<0.01$, and ${ }^{\star \star \star} P<0.001$.

the activation of $\mathrm{CD}^{+}$MALT1-deficient T cells, we stimulated splenocytes for $4 \mathrm{~h}$ with PMA/IO and determined the frequency of $\mathrm{CD} 44^{+} \mathrm{CD} 4{ }^{+} \mathrm{T}$ cells, so-called effector $\mathrm{CD} 4^{+} \mathrm{T}$ cells. Notably, Malt1-KO mice had a reduced frequency of effector $\mathrm{CD} 4^{+} \mathrm{T}$ cells (Figure 4B), which is consistent with previous findings (2).

Since not only Tregs but also effector $\mathrm{CD}^{+}{ }^{+} \mathrm{T}$ cells can use surface CTLA- 4 to suppress proliferation of effector $\mathrm{CD} 4^{+}$ $\mathrm{T}$ cells (54-56), we assessed the expression of CTLA-4 on the surface of effector $\mathrm{CD}^{+} \mathrm{T}$ cells from Malt1-KO and WT mice. In contrast to WT mice, Malt1-KO mice showed a strong reduction in the frequency of effector $\mathrm{CD} 4^{+} \mathrm{T}$ cells that express surface CTLA-4 (Figure 4C and gating strategy in
Supplementary Figure 2). In addition, the expression of CTLA4 on the remaining MALT1-deficient surface CTLA- $4^{+}$effector $\mathrm{CD}^{+}{ }^{+} \mathrm{T}$ cells was also reduced, as determined by the surface CTLA-4 mean fluorescent intensity (Figure 4D). These data clearly show that besides being important for CTLA-4 expression on the surface of Tregs, MALT1 is similarly important for the expression of CTLA-4 on the surface of effector CD4 ${ }^{+} \mathrm{T}$ cells. Together, these data show that although MALT1 deficiency leads to reduced activation and proliferation of stimulated $\mathrm{CD}^{+}{ }^{+} \mathrm{T}$ cells, it also lowers the immune suppressive functions of both Tregs and effector $\mathrm{CD}^{+} \mathrm{T}$ cells, which could contribute to disease development. 
A
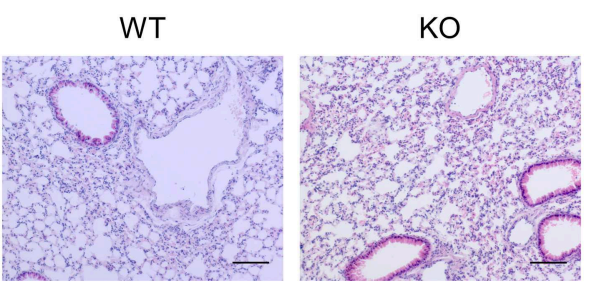

Liver
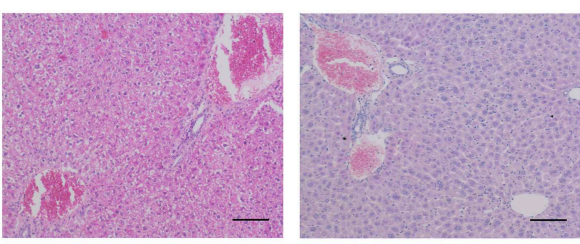

Colon
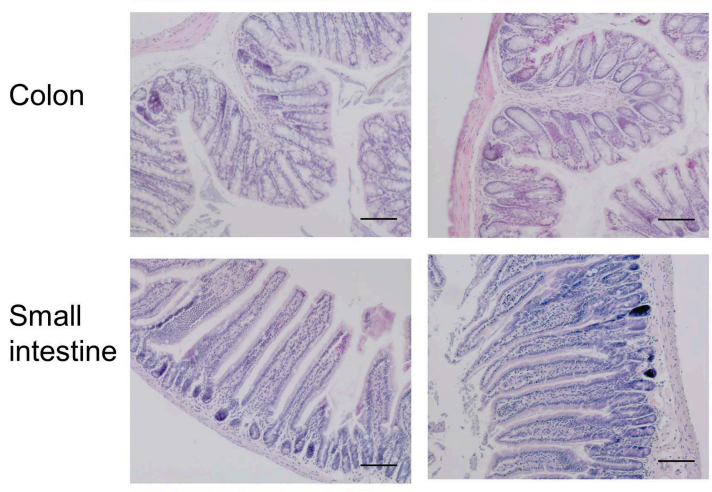

Stomach

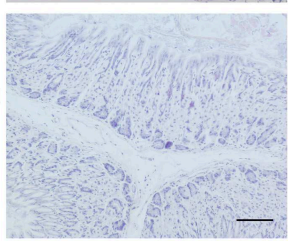

Salivary gland
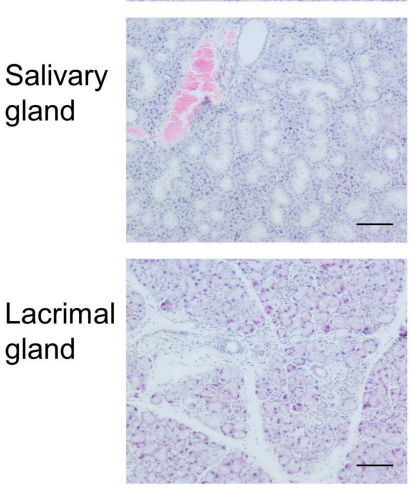

B
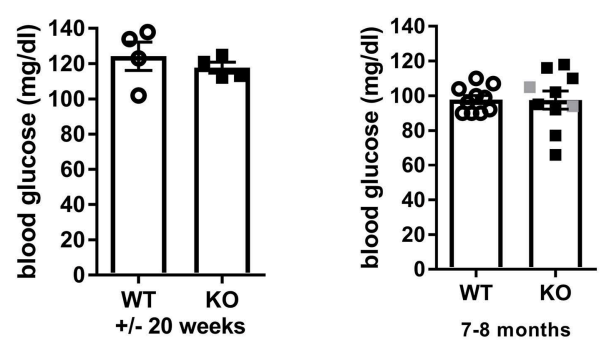

FIGURE 2 | Malt1-KO mice do not develop multi-organ inflammation. (A) H\&E staining (scale bar $100 \mu \mathrm{m}$ ) of several organs from WT and Malt1-KO mice

(Continued)
FIGURE 2 | (Malt1-KO mice had skin lesions and the WT and KO mice were between 30 and 40 weeks old). (B) Blood glucose levels in mice of \pm 20 weeks (left, WT: $n=5$ and KO: $n=4$ ) and mice of 7-8 months (right, WT: $n=10$ and $\mathrm{KO}: n=8)$. Open circles $(\mathrm{WT})$, gray squares $(\mathrm{KO})$, and black squares (KO + $\mathrm{AD}=\mathrm{KO}$ mice with atopic dermatitis) represent individual mice. The mean \pm SEM is indicated on the graphs. The statistical significance between groups was calculated with an unpaired 2-tailed Student's $t$-test: no significant difference was found.

\section{MALT1 Deficiency Causes Th2 Skewing Accompanied by Increased Serum IgE Levels}

We next investigated whether the impaired Treg development in Malt1-KO mice has an impact on the T-helper (Th) cell populations. To this end, we stimulated splenocytes with PMA, $\mathrm{IO}$, and Brefeldin A for $4 \mathrm{~h}$, and determined the percentage of Th2 (IL-4 producing $\mathrm{CD} 44^{+} \mathrm{CD} 4^{+} \mathrm{T}$ cells) (Figure 5A) and Th1 cells (IFN- $\gamma$ producing $\mathrm{CD} 44^{+} \mathrm{CD} 4^{+} \mathrm{T}$ cells) (Figure $5 \mathrm{~B}$ ), respectively (gating strategy in Supplementary Figure 3). MALT1-deficient mice ( \pm 20 weeks, skin lesion free) repeatedly showed largely similar levels of IFN- $\gamma$-producing Th1 cells, while the IL-4 producing Th2 cells were significantly increased. Since IL-4, secreted by Th2 cells, is known to induce B cell Ig isotype switching from $\operatorname{IgM}$ to $\operatorname{IgE}$ (57), we determined the serum IgE levels from Malt1-KO and WT mice of several ages. In agreement with the increased Th2 frequency, IgE levels were clearly elevated in Malt1-KO mice at any time point tested and preceded lesion onset (Figure 5C). Furthermore, in the ear skin of Malt1-KO mice with lesions, we found elevated mRNA levels of Tslp and Il22 (Figure 5D), which are both known to promote Th2 responses $(58,59)$. Collectively, these data indicate that MALT1 deficiency leads to Th2 skewing and IgE production, which might contribute to skin lesion development.

\section{DISCUSSION}

We report that aging Malt1-KO mice suffer from atopic-like dermatitis accompanied by elevated serum cytokine levels and preceded by Th2 skewing and elevated serum IgE levels. No inflammation could be observed at other sites of the body. In contrast to Malt1-KO mice, skin lesions were never reported in mice fully deficient in one of the other components of the CBM complex, BCL10 and CARD11, or in the upstream activator PKC $\theta$, even though BCL10 and PKCA deficient mice were followed up until 6 months of age $(22,60)$. Notably, despite being part of the same signaling pathway, MALT1, BCL10, and PKC- $\theta$ deficiency have also been reported to differentially affect TCRinduced proliferation, IL-2 production, and NF- $\mathrm{KB}$ activation in $\mathrm{T}$ cells, with MALT1-deficient $\mathrm{T}$ cells showing a milder impairment than BCL10- and PKC $\theta$-deficient $\mathrm{T}$ cells, suggesting they may have divergent functions and act in additional signaling pathways (61).

We further report that atopic-like dermatitis in aging Malt1$\mathrm{KO}$ mice is associated with a decrease in the number and function of Tregs in the thymus and periphery. We propose that the 


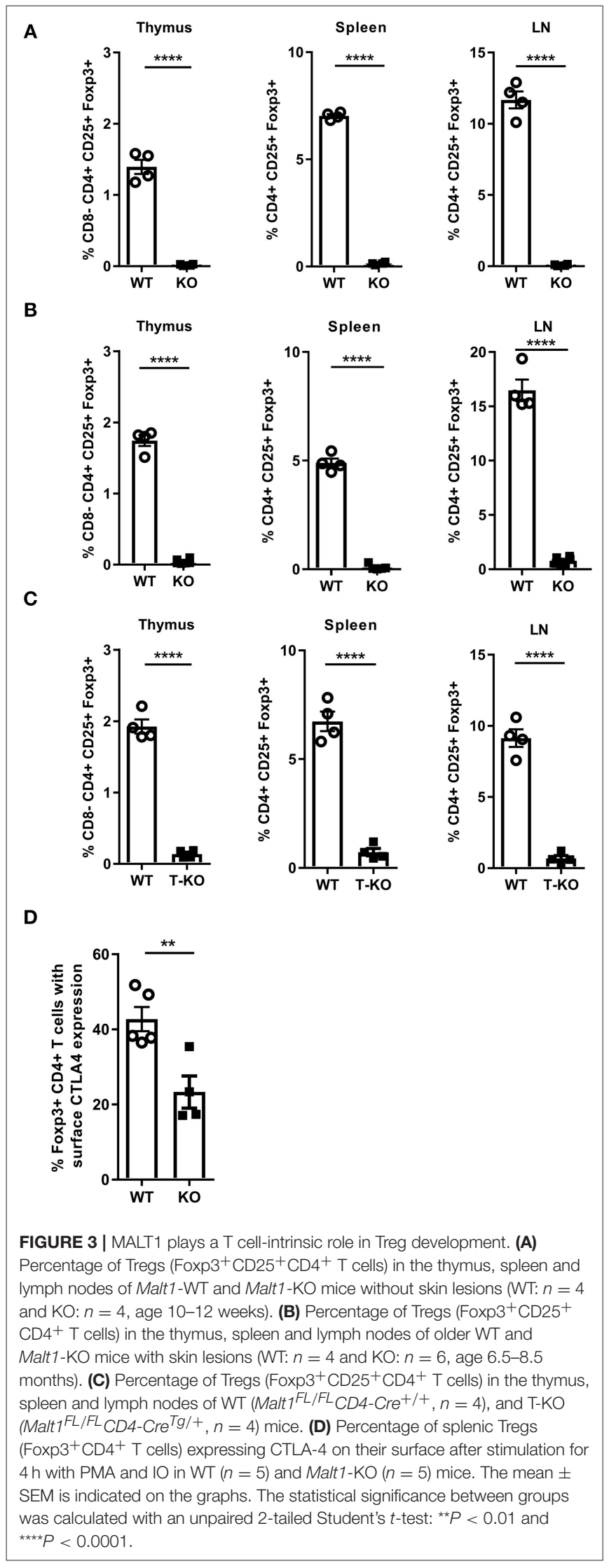

reduction in immune suppressive Tregs leads to a disruption of normal immune homeostasis and contributes to the activation of effector T cells and allergic skin inflammation. In this context, we could measure more Th2 cells producing IL-4, which is known to play multiple roles in promoting atopic-like dermatitis (62). A severe Treg reduction is also seen in patients suffering from immunodysregulation polyendocrinopathy enteropathy Xlinked (IPEX) syndrome (OMIM \#304790), caused by mutations in the FOXP3 gene (63) as well as mice with a mutation in the Foxp3 gene, so called scurfy mice (64). The scurfy mice and the IPEX patients illustrate variable autoimmune disorders. IPEX patients can suffer from type 1 diabetes mellitus and thyroid disease, increased IgE levels, asthma and food allergies, while dermatitis and increased IgE levels are also present in the scurfy mice $(63,65-67)$. A lack of functional Tregs is a common feature in Malt1-KO mice, scurfy mice and IPEX patients (44, 46, 50, 51, 68-70). Moreover, a scurfy-like phenotype was described for mice (Malt ${ }^{F L / F L}$ Foxp $\left.3-c r e^{T g /+}\right)$ with a specific deletion of Malt1 in Tregs $(36,49)$. However, while Malt1-KO mice as well as MALT1 CID patients display impaired T cell activation $(3,22,38-47)$, this is not the case for IPEX patients, scurfy mice and mice only lacking Malt1 in Tregs, where there is a failure to control $\mathrm{T}$ cell activation due to the absence of Tregs or the reduced functionality of Tregs leading to lymphoproliferation and autoimmunity, resulting in death $(36,49,63,65-67,71)$.

CTLA-4 is a known functionality marker on Tregs and is required for their inhibitory function $(52,53)$. We show that the remaining Tregs in Malt1-KO mice are also functionally impaired as demonstrated by a reduced CTLA- 4 expression. The reduced Treg frequency and functionality we observed in Malt1$\mathrm{KO}$ mice is associated with an increased Th2 frequency. Th2 cells were previously shown to expand disproportionally upon depletion of Tregs, which tightly control the Th2 population via induction of apoptosis of Th2, but not Th1 cells (72). Moreover, Tian et al. showed that addition of recombinant CTLA-4-Ig to Treg depleted mice induces Th2 apoptosis and thus reduces the Th2 expansion, illustrating the tight control by Tregs on the Th2 population (72). In addition to Tregs, also effector $\mathrm{CD}^{+} \mathrm{T}$ cells make use of surface CTLA-4 to inhibit effector $\mathrm{CD}^{+} \mathrm{T}$ cells, albeit with much lower efficiency than Tregs (5456). Notably, we show that CTLA-4 expression is also reduced on effector $\mathrm{CD}_{4}^{+} \mathrm{T}$ cells in Malt1-KO mice, which may also contribute to disease pathogenesis. Interestingly, CTLA-4 mRNA is post-transcriptionally regulated by the endonuclease Regnase1 and the RNA-binding proteins Roquin-1 and-2, which were shown to be inactivated by MALT1-mediated cleavage, leading to stabilization of CTLA-4 and many other mRNA molecules $(28,29)$. Most likely, reduced CTLA4 expression in MALT1deficient Tregs and effector $\mathrm{CD} 4^{+} \mathrm{T}$ cells reflects the absence of Regnase- 1 and Roquin cleavage, leading to CTLA-4 mRNA degradation and reduced CTLA-4 protein expression.

Mice that are completely deficient in MALT1 as well as mice expressing a catalytically inactive (protease-dead) mutant MALT1 have a reduced number of Tregs, but only Malt1-PD mice develop severe autoimmune symptoms (44-51). Impaired TCR-mediated effector T cell activation, normally mediated by the MALT1 scaffold function, has been proposed to prevent 
A

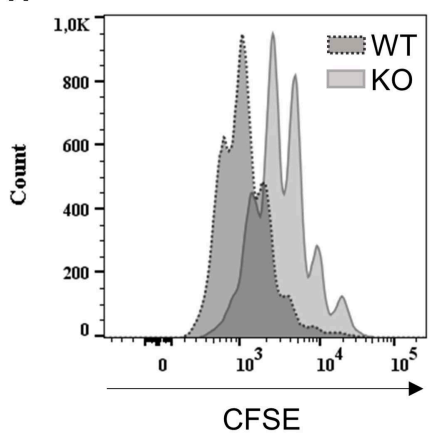

B

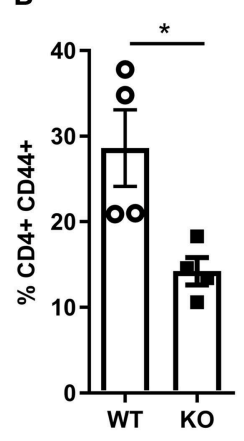

C

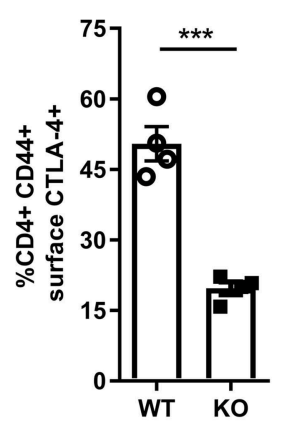

D

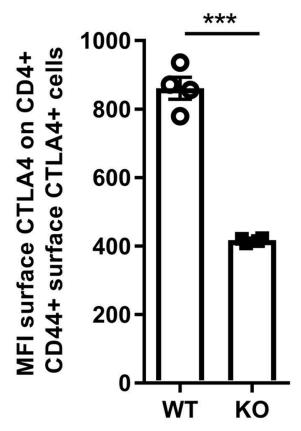

FIGURE 4 | Activation of Malt1-KO CD4 ${ }^{+} \mathrm{T}$ is altered. (A) CFSE labeled CD4 ${ }^{+}$T cells stimulated for $72 \mathrm{~h}$ with plate bound $\alpha$-CD3 and soluble $\alpha-C D 28$. The CFSE overlaid histograms displaying the proliferation of WT or Malt1-KO CD4 ${ }^{+} \mathrm{T}$ cells (age mice: 10 weeks lesion-free). (B) Splenocytes were stimulated for $4 \mathrm{~h}$ with PMA and $\mathrm{IO}$ (same for $\mathrm{C}$ and $\mathrm{D}$ ) in order to determine the percentage of CD44 ${ }^{+} \mathrm{CD} 4^{+} \mathrm{T}$ cells. (C) Percentage of CD44 ${ }^{+} \mathrm{CD} 4^{+} \mathrm{T}$ cells that express CTLA-4 on their surface. (D) Mean fluorescence intensity (MFI) of CTLA-4 on CD44+CD4+ ${ }^{+}$cells that express CTLA-4 on their surface. For (B-D) open circles (WT: $\left.n=4\right)$ and black squares (KO: $n=4)$ represent individual mice. The mean \pm SEM is indicated on the graphs. The statistical significance between groups was calculated with an unpaired 2-tailed Student's $t$-test: ${ }^{\star} P<0.05$ and ${ }^{\star \star \star} P<0.001$.
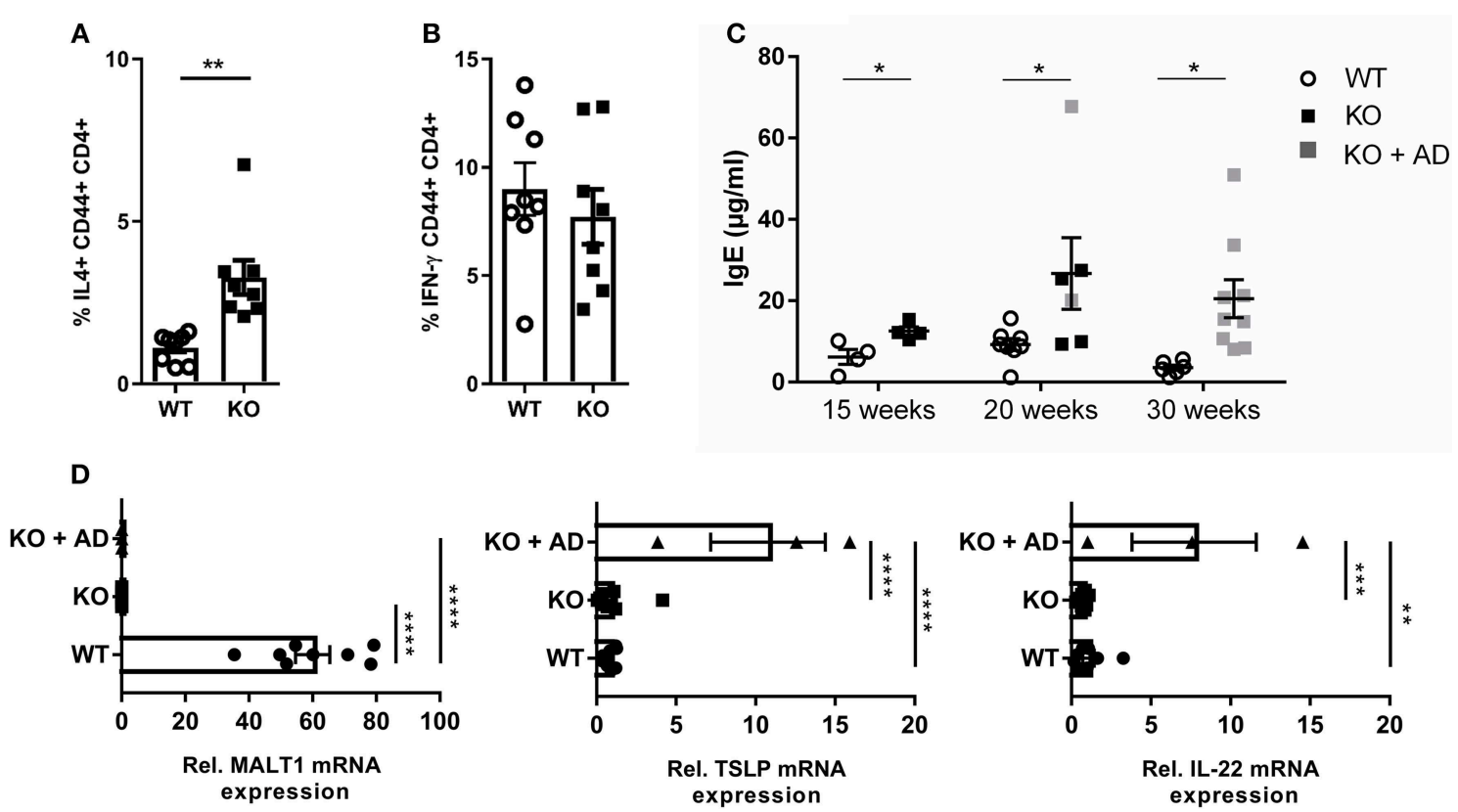

FIGURE 5 | Th2 skewing and elevated lgE levels in Malt1-KO mice. (A) Splenocytes of 20 weeks old mice without skin lesions were stimulated for $4 \mathrm{~h}$ with PMA and $\mathrm{IO}$ (same for B), in order to determine the percentage of CD44+ CD4 ${ }^{+}$T cells expressing IL-4 (WT and KO: $\left.n=8\right)$. (B) Percentage of CD44 ${ }^{+}$CD4 ${ }^{+}$T cells expressing IFN- $\gamma(\mathrm{WT}$ and KO: $n=8)$. (C) IgE levels in serum collected from WT and Malt1-KO mice of \pm 15 , \pm 20 , and $>30$ weeks (15 weeks WT and KO: $n=4$, at 20 weeks WT: $n=8$ and KO: $n=6$ and at 30 weeks WT: $n=6$ and KO: $n=9)$. Open circles (WT), black squares (KO), and gray squares (KO + AD) represent individual mice. (D) mRNA expression levels of Malt1, Ts/p, and IL22 (relative to reference genes Hprt1 and Ubc) in ears of Malt1-WT mice ( $n=7$ ), Malt1-KO mice ( $n=11$ ), and Malt1-KO + AD mice $(n=3)$ suffering from dermatitis. The mean \pm SEM is indicated on the graphs. For $(\mathbf{A}-\mathbf{C})$ all results were obtained by flow cytometry the statistical significance between groups was calculated with an unpaired 2-tailed Student's $t$-test. For (D) the statistical significance between groups was calculated with a one-way ANOVA with a Tukey's multiple comparison test. ${ }^{\star} P<0.05$, ${ }^{\star \star} P<0.01,{ }^{\star \star \star} P<0.001$, and ${ }^{\star \star \star \star} P<0.0001$.

spontaneous inflammation in full Malt1-KO mice (1). Our present finding that Malt1-KO mice spontaneously develop skin inflammation upon aging, implicates a role for MALT1independent antigen or cytokine receptor signaling leading to low or intermediate $\mathrm{T}$ cell activation. The reduced frequency of functional Tregs in combination with a lowered effector $\mathrm{T}$ cell activation causes a gradual and selective expansion of Th2 cells, culminating in allergic skin inflammation without autoimmunity or generalized inflammation.

Skin inflammation in atopic dermatitis is assumed to arise due to a misdirected immune response against harmless antigens on the one hand, and to skin barrier defects on the other hand 
(73). We propose that scratching may cause local skin barrier defects, which in combination with the Treg deficiency and the Th2 skewing favors the specific development of skin lesions in Malt1-KO mice. This is further supported by a report showing that tape stripping in combination with Treg depletion results in skin thickening, increased IL-4 and IL-13 mRNA levels in the skin, and elevated serum IgE levels (74). Of note, whereas an increase in IL- 4 was already detectable in Malt1-KO mice before the development of skin lesions, elevated levels of Tslp and Il22 mRNA, which are known to promote expression of Th2 cytokines, such as IL-4, could only be detected in lesional ear skin. A possible explanation might be that increased Tslp and Il22 levels only occur upon skin barrier disruption in skin lesions, which is in agreement with an observed increase in TSLP expression upon tape stripping $(75,76)$.

Persistent severe dermatitis (7/9) and increased serum IgE levels $(4 / 8)$ have been described in patients with loss of function mutations in MALT1 (38, 40-43). Similarly, dermatitis has been reported in genome-wide association studies for CARD11 (77) and is also one of the clinical features found in most patients with loss of function mutations in CARD11 (78-80). Also mice that have hypomorphic mutations in Card11 display dermatitis, reduced Tregs, and increased IgE and Th2 levels (81-83). The proposed mechanism for disease development is the tight relationship between Tregs and Th2 cell levels $(72,82)$. However, our T cell-specific Malt1-KO mice did not develop skin lesions, suggesting that absence of MALT1 in T cells only is not sufficient to drive skin inflammation in aging mice. CARD11 is a member of the CARD-CC protein family, which also contains CARD9, CARD10 (also known as CARMA3), and CARD14 (also known as CARMA2) (84), which can all form distinct CBM complexes in a cell-type specific manner. Recently, Peled at al. reported that two loss-of-function mutations in CARD14 are associated with atopic dermatitis (85). CARD14 is mainly expressed in keratinocytes and activates MALT1 signaling in keratinocytes $(86,87)$, which led us hypothesize that MALT1 deficiency in keratinocytes was driving atopic-like dermatitis. However, we also did not observe any skin lesions in keratinocyte-specific Malt1-KO mice. Possibly, combined deficiency in T cells and keratinocytes is needed to induce the atopic skin phenotype in aged mice. Alternatively, we cannot exclude a role for other cell types as well.

In general, the here established relationship between impaired MALT1-dependent TCR signaling, partial Treg deficiency, and dysregulated accumulation of Th2 cells, may provide a mechanistic basis to explain the allergic responses in patients carrying MALT1 and CARD11 mutations, and invites future studies investigating associations between atopy and genetic variations in other components of the TCR-MALT1 signaling pathway.

\section{MATERIALS AND METHODS}

\section{Mice}

Malt1-KO mice (backcrossed for more than 10 generations into C57BL/6 background) were a kind gift from Dr. T. Mak (Toronto, Canada). Another Malt1 allele from EUCOMM $\left(\right.$ Malt $\left.{ }^{\text {tmla(EUCOMM }) H m g u /+}\right)$ was derived from ES cells and subsequently back-crossed to germline-expressing Flpe-deleter mice (88) to generate a conditional Malt1-deficient allele $\left(\right.$ Malt $\left.1^{F L /+}\right)$. The ES cells were also backcrossed to a germlineexpressing Cre-deleter mouse (89) to obtain an alternative full deficient allele with a LacZ reporter (Malt $1^{\text {IRES-LacZ/+ }}$ ). To generate a T-cell specific knock-out, Malt $1^{F L /+}$ was further crossed to CD4-Cre $e^{T g /+}$ mice (90) and $\mathrm{K} 5-\mathrm{Cr} e^{\mathrm{Tg} /+}$ (91) and offspring was inter-crossed to select for Flpe-deleter-negative $\mathrm{T}$ cell-specific (Malt1 $\left.{ }^{\mathrm{FL} / \mathrm{FL}} \mathrm{CD} 4-\mathrm{Cre}^{\mathrm{Tg} /+}\right)$ and skin-specific (Malt1 $^{\mathrm{FL} / \mathrm{FL}} \mathrm{K5}$-Cre $\mathrm{Tg}^{\mathrm{Tg} /+}$ ) MALT1-deficient mice. CD4-Cre is always kept heterozygote by selecting one parent $C D 4-C r e^{T g /+}$ and the other parent as Cre-negative. The specificity of CD4-Cre was confirmed via western blot (Supplementary Figure 4) using rabbit monoclonal anti-MALT1 (SC-28246, Santa Cruz) and anti-Cre (6905-3, Merck Millipore). The K5-Cre is always kept heterozygote by selecting a male $\mathrm{K} 5-\mathrm{Cr} e^{\mathrm{Tg} /+}$ and a female as Cre-negative, to avoid female germline transmission (91). Mice were housed in individually ventilated cages in a specific pathogen-free (SPF) facility. Mice were supplied with water and food ad libitum and experiments were performed in compliance with the guidelines of the University of Ghent Ethics Committee for the use of laboratory animals (EC2011-024 and 2013-066). Mice were monitored regularly for signs of dermatitis, consisting of hair loss in the facial, ear and neck region, together with redness, skin thickening, and scratching.

\section{Genotyping}

For Malt1-KO-mice we used the primers MALT1-F (GTGCTC TTGTAA TTTTCTGTGCTC), MALT1 WT-R (GGGTACATC ATGGCCTGAACAGTTG), and MALT1 KO-R (GGGTGGGAT TAGATAAATGCCTGCTC), resulting in $172 \mathrm{bp}$ (WT) and 272 bp (KO) PCR products. The genotypings were made using GoTaq Green Hot Start (Promega) master mix, with a typical PCR program: $5 \mathrm{~min} 94^{\circ} \mathrm{C}$ denaturation, $35-40$ cycles $\left[45 \mathrm{~s} 94^{\circ} \mathrm{C} \mid 30 \mathrm{~s}\right.$ $60^{\circ} \mathrm{C} \mid 45 \mathrm{~s} 72^{\circ} \mathrm{C}$ ] and $10 \mathrm{~min} 72^{\circ} \mathrm{C}$ final elongation.

For the Malt1 ${ }^{\operatorname{tmla}(\mathrm{EUCOMM}) \mathrm{Hmgu} /+}$ derived mice we monitored the Malt1 Flox-allele or KO allele with the primers MALTcKO-F (GTTTCTCAGGTCTTTAGTTCATGTC), CoMLT-3-R (TAT ACTCTACATCTCCATGGT), MALTcKO-R (TTGTTTTGC AGATCTCTGCC), and MLT-LacZ-F (TCGCTACCATTACCA GTTGGT) resulting in 280 bp (WT), 400 bp (FL), 345 (KO), or 514 bp (KO-LacZ) PCR products. Flp was detected with the primers Flp-F (TTAGTTCAGCAGCACATGATG) and Flp-R (GGAGGATTTGATATTCACCTG), resulting in a 370 bp PCR fragment. K5-Cre was detected with the primers Cre-F (TGC CACGACCAAGTGACAGCAATG) and Cre-R (AGAGAC GGAAATCCATCGCTCG) producing a 374 bp PCR fragment. CD4-Cre was detected with primers CD4-Cre-R (TCAAGG CCAGACTAGGCTGCCTAT) and CD4-Cre-F2 (TCTCTGTGG CTGGCAGTTTCTCCA) producing a 300 bp PCR fragment. The genotypings were made using the GoTaq Green Hot Start (Promega) master mix, with a typical PCR program: $5 \mathrm{~min} 95^{\circ} \mathrm{C}$ denaturation, $35-40$ cycles $\left[30 \mathrm{~s} 95^{\circ} \mathrm{C} \mid 30\right.$ s $55-60^{\circ} \mathrm{C} \mid 60 \mathrm{~s} 72^{\circ} \mathrm{C}$ ] and $10 \mathrm{~min} 72^{\circ} \mathrm{C}$ final elongation. 


\section{Histology and Immunohistochemistry}

Skin, lung, liver, colon, small intestine, stomach, lacrimal gland, and salivary gland samples were fixed with $4 \%$ paraformaldehyde and imbedded in paraffin. Sections $(5 \mu \mathrm{m})$ were stained with hematoxylin and eosin. Skin sections were also stained with antiCD3 (clone CD3-12; Serotec). Images were acquired with a BX51 discussion microscope (Olympus) with PixeLink camera under $100 \times$ magnification .

\section{RNA Extraction, cDNA Synthesis, and Quantitative Real-Time PCR}

After sacrifice, ears were collected and incubated overnight in RNA later at $4^{\circ} \mathrm{C}$ before long term storage at $-70^{\circ} \mathrm{C}$. For RNA extraction, the ears were transferred to TRIzol reagent (Invitrogen) and homogenized using the Precellys 24 (Bertin technologies with CK26 beads). After phenol/chloroform phase separation, RNA was isolated using the Aurum total RNA mini kit (Bio-Rad). cDNA was synthesized using the SensiFAST ${ }^{\mathrm{TM}}$ cDNA synthesis kit (Bioline), according to manufacturer's instructions. Quantitative PCR was done with a LightCycler 480 (Roche) using sensiFAST ${ }^{\mathrm{TM}}$ SYBR NoROX kit (Bioline) with a total of $10 \mathrm{ng}$ cDNA and $300 \mathrm{nM}$ of specific primers in a $10 \mu \mathrm{l}$ reaction. Real-time reactions were done in triplicates. The following specific primers were used $\left(5^{\prime}-3^{\prime}\right)$ : Hprt1 Fwd AGTGTTGGATACAGGCCA GAC and Hprt Rev CGTGATTCAAATCCCTGAAGT; Ubc Fwd AGGTCAAACAGGAAGACAGACGTA and $U b c$ Rev TCA CACCCAAGAACAAGCACA; Malt1 Fwd GGACAAAGTCGC CCTTTTGAT and Rev TCCACAGCGTTACACATCTCA; Il22 Fwd AGACAGGTTCCAGCCCTACAT and Il22 Rev TCT TCTGGATGTTCTGGTCGT; Tslp Fwd TCTCAGGAGCCT CTTCATCCT and Tslp Rev CTCACAGTCCTCGATTTGCT. Analysis was done with qBase software (Biogazelle). Values were normalized to two reference genes, as determined by Genorm analysis.

\section{Blood Glucose Levels}

A drop of blood from the tail was applied to a test strip and the glucose level was measured with a Freestyle lite glucose meter (Abbot).

\section{Flow Cytometry Detection of Tregs}

Single cell suspensions of thymus, spleen, and lymph nodes were surfaced stained with Aqua Live/dead fixable stain (Life Technologies) or Fixable Viability Dye eFluor 506 (eBioscience), anti-CD16/CD32 Fc block (clone 2.4G2; BD Biosciences), antiCD3-V450 (clone 17A2; BD Biosciences) or anti-CD3 eFluor450 (clone 17A2; eBioscience), anti-CD4-FITC (clone GK1.5; BD Biosciences or eBioscience), anti-CD25-PercPcy5.5 (clone PC61; BD Biosciences) for $20 \mathrm{~min}$. Next, cells were permeabilized for $30 \mathrm{~min}$, followed by $30 \mathrm{~min}$ of intracellular staining for antiFoxp3-PE (clone FJK-16s; eBioscience). For the intracellular staining, the Foxp3 buffer set (eBioscience) was used and all incubation steps were done on ice.

\section{CTLA-4 Expression of Tregs and CD44 ${ }^{+}$CD4 ${ }^{+}$ Effector T Cells}

Splenocytes cultured in complete medium (RPMI 1640 medium supplemented with 10\% FCS, Sodium Pyruvate, L-glutamine, antibiotics, and 2-Mercaptoethanol) were stimulated with PMA $(50 \mathrm{ng} / \mathrm{ml})$ and ionomycin (IO) $(1 \mu \mathrm{g} / \mathrm{ml})$ for $4 \mathrm{~h}$ at $37^{\circ} \mathrm{C}$. The cells were stained as mentioned above, but anti-CD44APC-efluor780 (clone IM7; eBioscience) and anti-CTLA-4 PEeFluor610 (clone UC10-4B9; eBioscience) were also included in the surface staining.

\section{Analysis of Cytokines by Intracellular Cytokine Staining}

Splenocytes were cultured in complete medium and stimulated with PMA $(50 \mathrm{ng} / \mathrm{ml}), \mathrm{IO}(500 \mathrm{ng} / \mathrm{ml})$ and Brefeldin A $(1 \mu \mathrm{g} / \mathrm{ml})$ for $4-5 \mathrm{~h}$ at $37^{\circ} \mathrm{C}$. Stimulated cells were washed, surface stained with anti-CD16/CD32, Aqua Live/dead fixable stain or Fixable Viability Dye eFluor 506, anti-CD3-v450 or anti-CD3 eFluor450, anti-CD4-FITC, APC-anti-CD44-APC eFluor780, for $20 \mathrm{~min}$. Next, cells were fixed and permeabilized for $30 \mathrm{~min}$. using the Foxp3 buffer set, followed by intracellular staining with anti-IL4APC (clone 11B11; eBioscience) and anti-IFN $\gamma$-PE-Cy7 (clone XMG1.2; BD Pharmingen) for $30 \mathrm{~min}$.

\section{Proliferation of CD4 ${ }^{+} \mathrm{T}$ Cells}

$\mathrm{CD}^{+}{ }^{+} \mathrm{T}$ cells isolated with the MACS CD4 ${ }^{+} \mathrm{T}$ cell isolation kit II were labeled with $2.5 \mu \mathrm{M}$ CellTrace ${ }^{\mathrm{TM}}$ CFSE (Life Technologies) according to the manufacturer's protocol. The cells were cultured in complete medium for $72 \mathrm{~h}$ with $5 \mu \mathrm{g} / \mathrm{ml}$ plate bound anti-CD3 (145-2C11; BD Pharmingen) and $1 \mu \mathrm{g} / \mathrm{ml}$ soluble anti-CD28 (37.51; BD Pharmingen) and $50 \mathrm{IU} / \mathrm{ml}$ recombinant $\mathrm{mIL}-2$ (PSF, VIB). Cells were surface stained with Aqua Live/dead fixable stain, anti-CD4-FITC and fixed as mentioned above.

All data were obtained with a LSRII flow cytometer (BD Biosciences) and FlowJo Software (Treestar, Inc, Ashland, Ore) was used for data analysis.

\section{Analysis of IgE and Cytokines in Serum}

Peripheral blood samples were collected for serum preparation. The level of IgE in serum was determined using the mouse IgE ELISA Ready-SET-Go kit (eBioscience) and the concentration of IgE was calculated using GraphPad Prism 6 (GraphPad Software, Inc). The levels of IL-2 (171-G5003M), IL-4 (171-G5005M), IL6 (171-G5007M), IL-17 (171-G5013M), IFN- $\gamma$ (171-G5017M), and TNF (171-G5023M) was determined by Bio-Plex (Biorad) according to the manufacturer's conditions.

\section{Statistical Analysis}

Statistical analysis (indicated in the figure legends) was performed with GraphPad Prism 7.

\section{DATA AVAILABILITY STATEMENT}

All datasets generated for this study are included in the manuscript/Supplementary material. 


\section{ETHICS STATEMENT}

The animal study was reviewed and approved by University of Ghent Ethics Committee for the use of laboratory animals (EC2011-024 and 2013-066).

\section{AUTHOR CONTRIBUTIONS}

$\mathrm{AD}, \mathrm{DM}$, JS, and $\mathrm{RB}$ designed the experiments. $\mathrm{AD}$ performed all the experiments, except for Figure 1C (done by DM). EV and GB provided the technical assistance for Figure 5D and YD provided the technical assistance for Figure 3B. YD and MK assisted with the genotyping of mice. AD, JS, and RB contributed to the scientific discussion and wrote the manuscript.

\section{FUNDING}

Research in the authors' lab was supported by grants from the Fund for Scientific Research Flanders (FWO), Belgian

\section{REFERENCES}

1. Demeyer A, Staal J, Beyaert R. Targeting MALT1 proteolytic activity in immunity, inflammation and disease: good or bad? Trends Mol Med. (2016) 22:135-50. doi: 10.1016/j.molmed.2015.12.004

2. Ruland J, Duncan GS, Wakeham A, Mak TW. Differential requirement for Malt1 in T and B cell antigen receptor signaling. Immunity. (2003) 19:74958. doi: 10.1016/S1074-7613(03)00293-0

3. Ruefli-Brasse AA, French DM, Dixit VM. Regulation of NF-kappaBdependent lymphocyte activation and development by paracaspase. Science. (2003) 302:1581-4. doi: 10.1126/science.1090769

4. Akagi T, Motegi M, Tamura A, Suzuki R, Hosokawa Y, Suzuki H, et al. A novel gene, MALT1 at $18 \mathrm{q} 21$, is involved in $\mathrm{t}(11 ; 18)(\mathrm{q} 21 ; \mathrm{q} 21)$ found in low-grade B-cell lymphoma of mucosa-associated lymphoid tissue. Oncogene. (1999) 18:5785-94. doi: 10.1038/sj.onc. 1203018

5. Dierlamm J, Baens M, Wlodarska I, Stefanova-Ouzounova M, Hernandez JM, Hossfeld DK, et al. The apoptosis inhibitor gene API2 and a novel 18q gene, MLT, are recurrently rearranged in the $t(11 ; 18)(\mathrm{q} 21 ; \mathrm{q} 21)$ associated with mucosa-associated lymphoid tissue lymphomas. Blood. (1999) 93:3601-9.

6. Morgan JA, Yin Y, Borowsky AD, Kuo F, Nourmand N, Koontz JI, et al. Breakpoints of the $t(11 ; 18)(\mathrm{q} 21 ; \mathrm{q} 21)$ in mucosa-associated lymphoid tissue (MALT) lymphoma lie within or near the previously undescribed gene MALT1 in chromosome 18. Cancer Res. (1999) 59:6205-13.

7. Streubel B, Lamprecht A, Dierlamm J, Cerroni L, Stolte M, Ott G, et al. $\mathrm{T}(14 ; 18)(\mathrm{q} 32 ; \mathrm{q} 21)$ involving IGH and MALT1 is a frequent chromosomal aberration in MALT lymphoma. Blood. (2003) 101:23359. doi: 10.1182/blood-2002-09-2963

8. Lucas PC, Yonezumi M, Inohara N, McAllister-Lucas LM, Abazeed ME, Chen FF, et al. Bcl10 and MALT1, independent targets of chromosomal translocation in malt lymphoma, cooperate in a novel NF-kappa B signaling pathway. J Biol Chem. (2001) 276:19012-9. doi: 10.1074/jbc.M009984200

9. Ferch U, Kloo B, Gewies A, Pfander V, Duwel M, Peschel C, et al. Inhibition of MALT1 protease activity is selectively toxic for activated B cell-like diffuse large B cell lymphoma cells. J Exp Med. (2009) 206:231320. doi: 10.1084/jem.20091167102109c

10. Hailfinger S, Lenz G, Ngo V, Posvitz-Fejfar A, Rebeaud F, Guzzardi M, et al. Essential role of MALT1 protease activity in activated B cell-like diffuse large B-cell lymphoma. Proc Natl Acad Sci USA. (2009) 106:1994651. doi: 10.1073/pnas.0907511106

11. Hu S, Du MQ, Park SM, Alcivar A, Qu L, Gupta S, et al. cIAP2 is a ubiquitin protein ligase for BCL10 and is dysregulated in mucosa-associated lymphoid tissue lymphomas. J Clin Invest. (2006) 116:174-81. doi: 10.1172/JCI25641
Foundation Against Cancer; Ghent University Concerted Research Actions (GOA), the VIB Grand Challenges Program (VIB-GC01-C01). AD was supported by a pre-doctoral fellowship from the Agency for Innovation by Science and Technology (IWT). JS and DM were supported by a post-doctoral fellowship from the FWO.

\section{ACKNOWLEDGMENTS}

We would like to thank the VIB Flow Core and VIB Bioimaging Core for training, support, and access to the instrument park.

\section{SUPPLEMENTARY MATERIAL}

The Supplementary Material for this article can be found online at: https://www.frontiersin.org/articles/10.3389/fimmu. 2019.02330/full\#supplementary-material

12. Fontan L, Yang C, Kabaleeswaran V, Volpon L, Osborne MJ, Beltran E, et al. MALT1 small molecule inhibitors specifically suppress ABC-DLBCL in vitro and in vivo. Cancer Cell. (2012) 22:812-24. doi: 10.1016/j.ccr.2012.11.003

13. Nagel D, Spranger S, Vincendeau M, Grau M, Raffegerst S, Kloo B, et al. Pharmacologic inhibition of MALT1 protease by phenothiazines as a therapeutic approach for the treatment of aggressive ABC-DLBCL. Cancer Cell. (2012) 22:825-37. doi: 10.1016/j.ccr.2012.11.002

14. Langel FD, Jain NA, Rossman JS, Kingeter LM, Kashyap AK, Schaefer BC. Multiple protein domains mediate interaction between Bcl10 and MALT1. J Biol Chem. (2008) 283:32419-31. doi: 10.1074/jbc.M8006 70200

15. Sommer K, Guo B, Pomerantz JL, Bandaranayake AD, MorenoGarcia ME, Ovechkina YL, et al. Phosphorylation of the CARMA1 linker controls NF-kappaB activation. Immunity. (2005) 23:561-74. doi: 10.1016/j.immuni.2005.09.014

16. Matsumoto R, Wang D, Blonska M, Li H, Kobayashi M, Pappu $\mathrm{B}$, et al. Phosphorylation of CARMAl plays a critical role in $\mathrm{T}$ Cell receptor-mediated NF-kappaB activation. Immunity. (2005) 23:57585. doi: 10.1016/j.immuni.2005.10.007

17. Li S, Yang X, Shao J, Shen Y. Structural insights into the assembly of CARMA1 and BCL10. PLoS ONE. (2012) 7:e42775. doi: 10.1371/journal.pone.0042775

18. Knies N, Alankus B, Weilemann A, Tzankov A, Brunner K, Ruff T, et al. Lymphomagenic CARD11/BCL10/MALT1 signaling drives malignant B-cell proliferation via cooperative NF-kappaB and JNK activation. Proc Natl Acad Sci USA. (2015) 112:E7230-8. doi: 10.1073/pnas.1507459112

19. Sun L, Deng L, Ea CK, Xia ZP, Chen ZJ. The TRAF6 ubiquitin ligase and TAK1 kinase mediate IKK activation by BCL10 and MALT1 in T lymphocytes. Mol Cell. (2004) 14:289-301. doi: 10.1016/S1097-2765(04)00236-9

20. Oeckinghaus A, Wegener E, Welteke V, Ferch U, Arslan SC, Ruland J, et al. Malt1 ubiquitination triggers NF-kappaB signaling upon T-cell activation. EMBO J. (2007) 26:4634-45. doi: 10.1038/sj.emboj.7601897

21. Wu CJ, Ashwell JD. NEMO recognition of ubiquitinated Bcl10 is required for T cell receptor-mediated NF-kappaB activation. Proc Natl Acad Sci USA. (2008) 105:3023-8. doi: 10.1073/pnas.0712313105

22. Ruland J, Duncan GS, Elia A, del Barco Barrantes I, Nguyen L, Plyte $\mathrm{S}$, et al. Bcl10 is a positive regulator of antigen receptor-induced activation of NF-kappaB and neural tube closure. Cell. (2001) 104:3342. doi: 10.1016/S0092-8674(01)00189-1

23. Egawa T, Albrecht B, Favier B, Sunshine MJ, Mirchandani K, O’Brien $\mathrm{W}$, et al. Requirement for CARMA1 in antigen receptor-induced NFkappa B activation and lymphocyte proliferation. Curr Biol. (2003) 13:12528. doi: 10.1016/S0960-9822(03)00491-3 
24. Rebeaud F, Hailfinger S, Posevitz-Fejfar A, Tapernoux M, Moser R, Rueda $\mathrm{D}$, et al. The proteolytic activity of the paracaspase MALT1 is key in T cell activation. Nat Immunol. (2008) 9:272-81. doi: 10.1038/ni1568

25. Coornaert B, Baens M, Heyninck K, Bekaert T, Haegman M, Staal J, et al. $\mathrm{T}$ cell antigen receptor stimulation induces MALT1 paracaspase-mediated cleavage of the NF-kappaB inhibitor A20. Nat Immunol. (2008) 9:26371. doi: $10.1038 /$ ni1561

26. Staal J, Driege Y, Bekaert T, Demeyer A, Muyllaert D, Van Damme P, et al. T-cell receptor-induced JNK activation requires proteolytic inactivation of CYLD by MALT1. EMBO J. (2011) 30:1742-52. doi: 10.1038/emboj.2011.85

27. Hailfinger S, Nogai H, Pelzer C, Jaworski M, Cabalzar K, Charton JE, et al. Malt1-dependent RelB cleavage promotes canonical NF-kappaB activation in lymphocytes and lymphoma cell lines. Proc Natl Acad Sci USA. (2011) 108:14596-601. doi: 10.1073/pnas.1105020108

28. Jeltsch KM, Hu D, Brenner S, Zoller J, Heinz GA, Nagel D, et al. Cleavage of roquin and regnase- 1 by the paracaspase MALT1 releases their cooperatively repressed targets to promote $\mathrm{T}(\mathrm{H}) 17$ differentiation. Nat Immunol. (2014) 15:1079-89. doi: 10.1038/ni.3008

29. Uehata T, Iwasaki H, Vandenbon A, Matsushita K, Hernandez-Cuellar E, Kuniyoshi K, et al. Malt1-induced cleavage of regnase-1 in CD4(+) helper T cells regulates immune activation. Cell. (2013) 153:103649. doi: 10.1016/j.cell.2013.04.034

30. Klein T, Fung SY, Renner F, Blank MA, Dufour A, Kang S, et al. The paracaspase MALT1 cleaves HOIL1 reducing linear ubiquitination by LUBAC to dampen lymphocyte NF-kappaB signalling. Nat Commun. (2015) 6:8777. doi: $10.1038 /$ ncomms9777

31. Elton L, Carpentier I, Staal J, Driege Y, Haegman M, Beyaert R. MALT1 cleaves the E3 ubiquitin ligase HOIL-1 in activated T cells, generating a dominant negative inhibitor of LUBAC-induced NF-kappaB signaling. FEBS J. (2016) 283:403-12. doi: 10.1111/febs.13597

32. Douanne T, Gavard J, Bidere N. The paracaspase MALT1 cleaves the LUBAC subunit HOIL1 during antigen receptor signaling. J Cell Sci. (2016) 129:177580. doi: $10.1242 /$ jcs. 185025

33. Baens M, Bonsignore L, Somers R, Vanderheydt C, Weeks SD, Gunnarsson J, et al. MALT1 auto-proteolysis is essential for NF-kappaB-dependent gene transcription in activated lymphocytes. PLoS ONE. (2014) 9:e103774. doi: 10.1371/journal.pone.0103774

34. Yamasoba D, Sato K, Ichinose T, Imamura T, Koepke L, Joas S, et al. N4BP1 restricts HIV-1 and its inactivation by MALT1 promotes viral reactivation. Nat Microbiol. (2019) 4:1532-44. doi: 10.1038/s41564-019-0460-3

35. Mc Guire C, Elton L, Wieghofer P, Staal J, Voet S, Demeyer A, et al. Pharmacological inhibition of MALT1 protease activity protects mice in a mouse model of multiple sclerosis. J Neuroinflammation. (2014) 11:124. doi: 10.1186/1742-2094-11-124

36. Rosenbaum M, Gewies A, Pechloff K, Heuser C, Engleitner T, Gehring $\mathrm{T}$, et al. Bcl10-controlled Malt1 paracaspase activity is key for the immune suppressive function of regulatory T cells. Nat Commun. (2019) 10:2352. doi: 10.1038/s41467-019-10203-2

37. Di Pilato M, Kim EY, Cadilha BL, Prussmann JN, Nasrallah MN, Seruggia D, et al. Targeting the CBM complex causes Treg cells to prime tumours for immune checkpoint therapy. Nature. (2019) 570:1126. doi: 10.1038/s41586-019-1215-2

38. McKinnon ML, Rozmus J, Fung SY, Hirschfeld AF, Del Bel KL, Thomas $\mathrm{L}$, et al. Combined immunodeficiency associated with homozygous MALT1 mutations. J Allergy Clin Immunol. (2013) 133:1458-62, 1462.e1-7. doi: 10.1016/j.jaci.2013.10.045

39. Jabara HH, Ohsumi T, Chou J, Massaad MJ, Benson H, Megarbane A, et al. A homozygous mucosa-associated lymphoid tissue 1 (MALT1) mutation in a family with combined immunodeficiency. J Allergy Clin Immunol. (2013) 132:151-8. doi: 10.1016/j.jaci.2013.04.047

40. Punwani D, Wang H, Chan AY, Cowan MJ, Mallott J, Sunderam U, et al. Combined immunodeficiency due to MALT1 mutations, treated by hematopoietic cell transplantation. J Clin Immunol. (2015) 35:13546. doi: 10.1007/s10875-014-0125-1

41. Charbit-Henrion F, Jeverica AK, Begue B, Markelj G, Parlato M, Avcin $\mathrm{SL}$, et al. Deficiency in mucosa-associated lymphoid tissue lymphoma translocation 1: a novel cause of IPEX-like syndrome. J Pediatr Gastroenterol Nutr. (2017) 64:378-84. doi: 10.1097/MPG.0000000000001262
42. Wiegmann H, Reunert J, Metze D, Marquardt T, Engel T, Kunde V, et al. Refining the dermatological spectrum in primary immunodeficiency: MALT1 deficiency mimicking Netherton- and Omenn syndrome. Br J Dermatol. (2019). doi: 10.1111/bjd.18091. [Epub ahead of print].

43. Frizinsky S, Rechavi E, Barel O, Najeeb RH, Greenberger S, Lee YN, et al. Novel MALT1 mutation linked to immunodeficiency, immune dysregulation, and an abnormal T cell receptor repertoire. J Clin Immunol. (2019) 39:40113. doi: 10.1007/s10875-019-00629-0

44. Jaworski M, Marsland BJ, Gehrig J, Held W, Favre S, Luther SA, et al. Malt1 protease inactivation efficiently dampens immune responses but causes spontaneous autoimmunity. EMBO J. (2014) 33:2765-81. doi: 10.15252/embj.201488987

45. Yu JW, Hoffman S, Beal AM, Dykon A, Ringenberg MA, Hughes AC, et al. MALT1 protease activity is required for innate and adaptive immune responses. PLoS ONE. (2015) 10:e0127083. doi: 10.1371/journal.pone.0127083

46. Bornancin F, Renner F, Touil R, Sic H, Kolb Y, Touil-Allaoui I, et al. Deficiency of MALT1 paracaspase activity results in unbalanced regulatory and effector T and B cell responses leading to multiorgan inflammation. J Immunol. (2015) 194:3723-34. doi: 10.4049/jimmunol.1402254

47. Gewies A, Gorka O, Bergmann H, Pechloff K, Petermann F, Jeltsch KM, et al. Uncoupling Malt1 threshold function from paracaspase activity results in destructive autoimmune inflammation. Cell Rep. (2014) 9:1292305. doi: 10.1016/j.celrep.2014.10.044

48. Demeyer A, Skordos I, Driege Y, Kreike M, Hochepied T, Baens M, et al. MALT1 proteolytic activity suppresses autoimmunity in a $\mathrm{T}$ cell intrinsic manner. Front Immunol. (2019) 10:1898. doi: 10.3389/fimmu.2019.01898

49. Cheng L, Deng N, Yang N, Zhao X, Lin X. Malt1 protease is critical in maintaining function of regulatory $\mathrm{T}$ cells and may be a therapeutic target for antitumor immunity. J Immunol. (2019) 202:3008-19. doi: 10.4049/jimmunol.1801614

50. Mc Guire C, Wieghofer P, Elton L, Muylaert D, Prinz M, Beyaert R, et al. Paracaspase MALT1 deficiency protects mice from autoimmune-mediated demyelination. J Immunol. (2013) 190:2896-903. doi: 10.4049/jimmunol.1201351

51. Brüstle A, Brenner D, Knobbe-Thomsen CB, Cox M, Lang PA, Lang KS, et al. MALT1 is an intrinsic regulator of regulatory T cells. Cell Death Differ. (2017) 24:1214-23. doi: 10.1038/cdd.2015.104

52. Walker LS, Sansom DM. The emerging role of CTLA4 as a cellextrinsic regulator of T cell responses. Nat Rev Immunol. (2011) 11:85263. doi: $10.1038 /$ nri3108

53. Walker LS, Sansom DM. Confusing signals: recent progress in CTLA-4 biology. Trends Immunol. (2015) 36:63-70. doi: 10.1016/j.it.2014.12.001

54. Wang CJ, Kenefeck R, Wardzinski L, Attridge K, Manzotti C, Schmidt EM, et al. Cutting edge: cell-extrinsic immune regulation by CTLA4 expressed on conventional T cells. J Immunol. (2012) 189:111822. doi: 10.4049/jimmunol.1200972

55. Tai X, Van Laethem F, Pobezinsky L, Guinter T, Sharrow SO, Adams A, et al. Basis of CTLA-4 function in regulatory and conventional CD4(+) T cells. Blood. (2012) 119:5155-63. doi: 10.1182/blood-2011-11-388918

56. Corse E, Allison JP. Cutting edge: CTLA-4 on effector T cells inhibits in trans. J Immunol. (2012) 189:1123-7. doi: 10.4049/jimmunol.12 00695

57. Geha RS, Jabara HH, Brodeur SR. The regulation of immunoglobulin E class-switch recombination. Nat Rev Immunol. (2003) 3:72132. doi: $10.1038 /$ nril181

58. Lou H, Lu J, Choi EB, Oh MH, Jeong M, Barmettler S, et al. Expression of IL-22 in the skin causes Th2-biased immunity, epidermal barrier dysfunction, and pruritus via stimulating epithelial Th2 cytokines and the GRP pathway. $J$ Immunol. (2017) 198:2543-55. doi: 10.4049/jimmunol.1600126

59. Cianferoni A, Spergel J. The importance of TSLP in allergic disease and its role as a potential therapeutic target. Expert Rev Clin Immunol. (2014) 10:1463-74. doi: 10.1586/1744666X.2014.967684

60. Van Beek M, Oravecz-Wilson KI, Delekta PC, Gu S, Li X, Jin X, et al. Bcl10 links saturated fat overnutrition with hepatocellular NF-kB activation and insulin resistance. Cell Rep. (2012) 1:444-52. doi: 10.1016/j.celrep.2012.04.006

61. Kingeter LM, Schaefer BC. Loss of protein kinase C theta, Bcl10, or Malt1 selectively impairs proliferation and NF-kappa B activation in the CD4+ T cell subset. J Immunol. (2008) 181:6244-54. doi: 10.4049/jimmunol.181.9.6244 
62. Sehra S, Yao Y, Howell MD, Nguyen ET, Kansas GS, Leung DY, et al. IL-4 regulates skin homeostasis and the predisposition toward allergic skin inflammation. J Immunol. (2010) 184:318690. doi: 10.4049/jimmunol.0901860

63. d'Hennezel E, Bin Dhuban K, Torgerson T, Piccirillo CA. The immunogenetics of immune dysregulation, polyendocrinopathy, enteropathy, X linked (IPEX) syndrome. J Med Genet. (2012) 49:291-302. doi: 10.1136/jmedgenet-2012-100759

64. Ramsdell F, Ziegler SF. FOXP3 and scurfy: how it all began. Nat Rev Immunol. (2014) 14:343-9. doi: 10.1038/nri3650

65. Wildin RS, Smyk-Pearson S, Filipovich AH. Clinical and molecular features of the immunodysregulation, polyendocrinopathy, enteropathy, X linked (IPEX) syndrome. J Med Genet. (2002) 39:537-45. doi: 10.1136/jmg.39.8.537

66. Godfrey VL, Wilkinson JE, Russell LB. X-linked lymphoreticular disease in the scurfy (sf) mutant mouse. Am J Pathol. (1991) 138:1379-87.

67. Ju ST, Sharma R, Gaskin F, Kung JT, Fu SM. The biology of autoimmune response in the scurfy mice that lack the CD4+Foxp3+ regulatory T-cells. Biology. (2012) 1:18-42. doi: 10.3390/biology1010018

68. Lahl K, Mayer CT, Bopp T, Huehn J, Loddenkemper C, Eberl G, et al. Nonfunctional regulatory $\mathrm{T}$ cells and defective control of Th2 cytokine production in natural scurfy mutant mice. J Immunol. (2009) 183:566272. doi: 10.4049/jimmunol.0803762

69. Fontenot JD, Gavin MA, Rudensky AY. Foxp3 programs the development and function of CD4+CD25+ regulatory T cells. Nat Immunol. (2003) 4:3306. doi: 10.1038/ni904

70. Bacchetta R, Barzaghi F, Roncarolo MG. From IPEX syndrome to FOXP3 mutation: a lesson on immune dysregulation. Ann N Y Acad Sci. (2016) 1417:5-22. doi: 10.1111/nyas.13011

71. Brunkow ME, Jeffery EW, Hjerrild KA, Paeper B, Clark LB, Yasayko SA, et al. Disruption of a new forkhead/winged-helix protein, scurfin, results in the fatal lymphoproliferative disorder of the scurfy mouse. Nat Genet. (2001) 27:68-73. doi: 10.1038/83784

72. Tian L, Altin JA, Makaroff LE, Franckaert D, Cook MC, Goodnow CC, et al. Foxp3 $(+)$ regulatory $\mathrm{T}$ cells exert asymmetric control over murine helper responses by inducing Th2 cell apoptosis. Blood. (2011) 118:184553. doi: 10.1182/blood-2011-04-346056

73. Roesner LM, Werfel T, Heratizadeh A. The adaptive immune system in atopic dermatitis and implications on therapy. Expert Rev Clin Immunol. (2016) 12:787-96. doi: 10.1586/1744666X.2016.1165093

74. Fyhrquist N, Lehtimaki S, Lahl K, Savinko T, Lappetelainen AM, Sparwasser $\mathrm{T}$, et al. Foxp3 + cells control Th2 responses in a murine model of atopic dermatitis. J Invest Dermatol. (2012) 132:1672-80. doi: 10.1038/jid.2012.40

75. Oyoshi MK, Larson RP, Ziegler SF, Geha RS. Mechanical injury polarizes skin dendritic cells to elicit a $\mathrm{T}(\mathrm{H}) 2$ response by inducing cutaneous thymic stromal lymphopoietin expression. J Allergy Clin Immunol. (2010) 126:97684, 84.e1-5. doi: 10.1016/j.jaci.2010.08.041

76. Leyva-Castillo JM, Hener P, Jiang H, Li M. TSLP produced by keratinocytes promotes allergen sensitization through skin and thereby triggers atopic march in mice. J Invest Dermatol. (2013) 133:154-63. doi: 10.1038/jid.2012.239

77. Hirota T, Takahashi A, Kubo M, Tsunoda T, Tomita K, Sakashita M, et al. Genome-wide association study identifies eight new susceptibility loci for atopic dermatitis in the Japanese population. Nat Genet. (2012) 44:12226. doi: $10.1038 / \mathrm{ng} .2438$

78. Ma CA, Stinson JR, Zhang Y, Abbott JK, Weinreich MA, Hauk PJ, et al. Germline hypomorphic CARD11 mutations in severe atopic disease. Nat Genet. (2017) 49:1192-201. doi: 10.1038/ng.3898

79. Dadi H, Jones TA, Merico D, Sharfe N, Ovadia A, Schejter Y, et al. Combined immunodeficiency and atopy caused by a dominant negative mutation in caspase activation and recruitment domain family member 11 (CARD11). J Allergy Clin Immunol. (2017) 141:1818-30.e2. doi: 10.1016/j.jaci.2017.06.047
80. Dorjbal B, Stinson JR, Ma CA, Weinreich MA, Miraghazadeh B, Hartberger $\mathrm{JM}$, et al. Hypomorphic caspase activation and recruitment domain 11 (CARD11) mutations associated with diverse immunologic phenotypes with or without atopic disease. Jo Allergy Clin Immunol. (2019) 143:148295. doi: 10.1016/j.jaci.2018.08.013

81. Barnes MJ, Krebs P, Harris N, Eidenschenk C, GonzalezQuintial R, Arnold $\mathrm{CN}$, et al. Commitment to the regulatory $\mathrm{T}$ cell lineage requires CARMAl in the thymus but not in the periphery. PLoS Biol. (2009) 7:e51. doi: 10.1371/journal.pbio.10 00051

82. Altin JA, Tian L, Liston A, Bertram EM, Goodnow CC, Cook MC. Decreased T-cell receptor signaling through CARD11 differentially compromises forkhead box protein 3-positive regulatory versus $\mathrm{T}(\mathrm{H}) 2$ effector cells to cause allergy. J Allergy Clin Immunol. (2011) 127:1277-85.e5. doi: 10.1016/j.jaci.2010.12.1081

83. Policheni A, Horikawa K, Milla L, Kofler J, Bouillet P, Belz GT, et al. CARD11 is dispensable for homeostatic responses and suppressive activity of peripherally-induced FOXP3+ regulatory T cells. Immunol Cell Biol. (2019) 97:740-52. doi: 10.1111/imcb.12268

84. Staal J, Driege Y, Haegman M, Borghi A, Hulpiau P, Lievens L, et al. Ancient origin of the CARD-coiled coil/Bcl10/MALT1-like paracaspase signaling complex indicates unknown critical functions. Front Immunol. (2018) 9:1136. doi: 10.3389/fimmu.2018.01136

85. Peled A, Sarig O, Sun G, Samuelov L, Ma CA, Zhang Y, et al. Lossof-function mutations in caspase recruitment domain-containing protein 14 (CARD14) are associated with a severe variant of atopic dermatitis. J Allergy Clin Immunol. (2019) 143:173-81.e10. doi: 10.1016/j.jaci.2018. 09.002

86. Afonina IS, Van Nuffel E, Baudelet G, Driege Y, Kreike M, Staal J, et al. The paracaspase MALT1 mediates CARD14-induced signaling in keratinocytes. EMBO Rep. (2016) 17:914-27. doi: 10.15252/embr.2016 42109

87. Van Nuffel E, Schmitt A, Afonina IS, Schulze-Osthoff K, Beyaert R, Hailfinger S. CARD14-mediated activation of paracaspase MALT1 in keratinocytes: implications for psoriasis. J Invest Dermatol. (2017) 137:56975. doi: 10.1016/j.jid.2016.09.031

88. Rodriguez CI, Buchholz F, Galloway J, Sequerra R, Kasper J, Ayala R, et al. High-efficiency deleter mice show that FLPe is an alternative to Cre-loxP. Nat Genet. (2000) 25:139-40. doi: 10.1038/75973

89. Betz UA, Vosshenrich CA, Rajewsky K, Muller W. Bypass of lethality with mosaic mice generated by Cre-loxP-mediated recombination. Curr Biol. (1996) 6:1307-16. doi: 10.1016/S0960-9822(02)70717-3

90. Wolfer A, Bakker T, Wilson A, Nicolas M, Ioannidis V, Littman DR, et al. Inactivation of Notch 1 in immature thymocytes does not perturb CD4 or CD8T cell development. Nat Immunol. (2001) 2:235-41. doi: 10.1038/85294

91. Ramirez A, Page A, Gandarillas A, Zanet J, Pibre S, Vidal M, et al. A keratin K5Cre transgenic line appropriate for tissue-specific or generalized Cremediated recombination. Genesis. (2004) 39:52-7. doi: 10.1002/gene.20025

Conflict of Interest: The authors declare that the research was conducted in the absence of any commercial or financial relationships that could be construed as a potential conflict of interest.

Copyright (C) 2019 Demeyer, Van Nuffel, Baudelet, Driege, Kreike, Muyllaert, Staal and Beyaert. This is an open-access article distributed under the terms of the Creative Commons Attribution License (CC BY). The use, distribution or reproduction in other forums is permitted, provided the original author(s) and the copyright owner(s) are credited and that the original publication in this journal is cited, in accordance with accepted academic practice. No use, distribution or reproduction is permitted which does not comply with these terms. 